\title{
Logistic Approach to the Management of Regional Innovative Development in the Conditions of the Digital Economy (on the Example of the Moscow Region)
}

\author{
Khoroshavina N.S. \\ LEONOV Moscow Region University of Technology, \\ Korolev, Russia, \\ nataxoroshavina@mail.ru
}

\author{
Nikolaev V.I. \\ LEONOV Moscow Region University of Technology, \\ Korolev, Russia, \\ NikolaevVladislav96@ya.ru
}

\author{
Trifonov V.A. \\ Yaroslav-the-Wise Novgorod State University, \\ Veliky Novgorod, Russia, \\ tva@novsu.ru
}

\begin{abstract}
Regional innovative development is the basis for the country's innovative breakthrough. This circumstance becomes especially relevant in the context of the digitalization of the Russian economy. After all, it is innovation that becomes the starting point of digital transformation. In this regard, it becomes necessary to search for an effective approach to the management of regional innovative development. Logistic approach can be used as such an approach. The object of research of this article is the Moscow region, as the leading subject of the Russian Federation in innovative development, as well as the center of concentration of flow processes. On the materials of this region, the essence of the main and accompanying flows arising in the course of the implementation of innovative activities is revealed. The article discusses the logistics links of the regional innovation system, and also determines that the most important form of implementing the logistics approach at the regional level is the territorial innovation cluster. Based on the study, it was concluded that the use of a logistic approach in managing the innovative development of a region should be based on compliance with a number of provisions. This will ensure the optimization of the flow processes of the regional innovation system and increase the efficiency of its functioning.
\end{abstract}

Keywords—logistic approach, regional innovative development

\section{INTRODUCTION}

The digital transformation of the Russian economy requires the acceleration of innovative development. Digitalization is impossible without innovation. After all, it is innovation that is the foundation of the digital economy. At the same time, the acceleration of innovative development should take place both at the level of the state as a whole and at the regional level. Moreover, it is the regional innovative development that is the basis for the country's innovative breakthrough.

The Moscow region plays an important role in the innovative development of the Russian state. According to the rating of innovative development of the subjects of the Russian Federation, published by the NRU HSE in 2019, the Moscow region is among the top ten leaders in terms of innovative development. Thus, the Moscow region ranked sixth in the integral index of innovative development of regions, behind only Moscow, the Republic of Tatarstan, Saint Petersburg, Nizhny Novgorod and Tomsk regions. At the same time, compared to the 2017 rating data, the Moscow Region has significantly improved its position, having risen from the 14th place. Moscow has been in the top three for several years already, and according to the rating published in 2019, it takes first place [1]

The Moscow region acts not only as the center of the country, but also as a center for the formation of financial, material, labor, innovation and other flows. In this regard, the use of a logistic approach in managing the innovative development of a given region is becoming especially relevant.

\section{RESULTS AND DISCUSSION}

In contrast to the traditional approach, in the case of a logistic control object, first of all, the flow appears. When it comes to regional innovative development, the main one here is the innovation flow, and the material, financial, labor and other flows are related to accompanying, which provide the 
conditions for the purposeful movement of this innovative flow.

The innovation flow is the movement of technologies, patents, licenses, industrial designs between the subjects of innovation, which contributes to the transformation of innovation into innovation [2]. Thus, the intensity of the innovation flow will be determined by the number of issued patents for inventions, utility models, industrial designs, as well as the number of developed advanced industrial technologies [3].

In terms of the intensity of the innovation flow in the field of patenting, the Moscow region occupies a leading position among all subjects of the Russia. It accounts for $32 \%$ of all patents for inventions issued in Russia, 29\% are issued for utility models and 47\% - for industrial designs (Fig. 1).

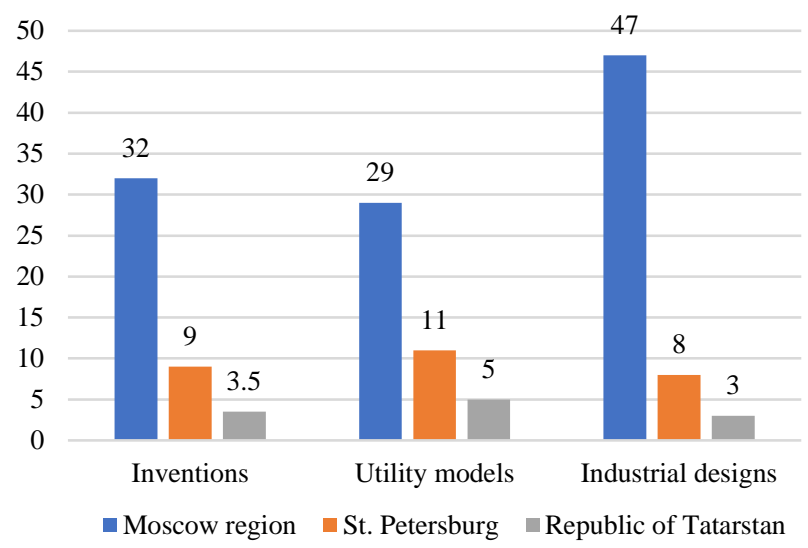

Fig. 1. The share of the Moscow region in the total set of issued patents in the Russian Federation in comparison with the leading regions, \%

In terms of the number of advanced industrial technologies developed, the Moscow region also has no equal. It accounts for almost a quarter of all innovative technologies developed in Russia in industrial production (Fig. 2).

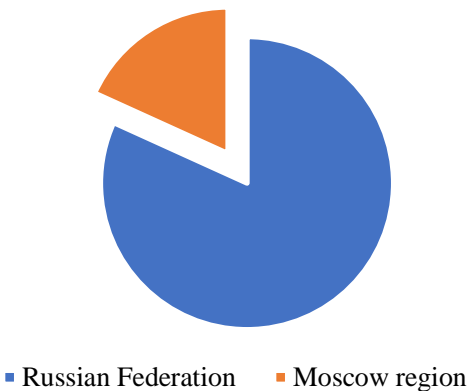

Fig. 2. The share of the Moscow region in the total set of developed advanced industrial technologies

The innovation flow will be effective only if it is accompanied by other types of flows. In particular, material and financial flows.

The material flow in the innovation sphere is the movement of material resources (raw materials, materials, semi-finished products, etc.) necessary for the implementation of the innovation process, as well as finished products to the consumer, which are innovative goods, works or services [4].

In the Moscow region, there is an annual growth in the volume of shipped innovative goods, works and services, which indicates an increase in the intensity of movement of the material flow. So, for example, in 2019 the value of this indicator was almost 20 trillion rubles, which is almost twice as much as in 2018. In terms of the volume of innovative products, works and services, the Moscow region is also the leader among all constituent entities of the Russian Federation (Fig. 3).

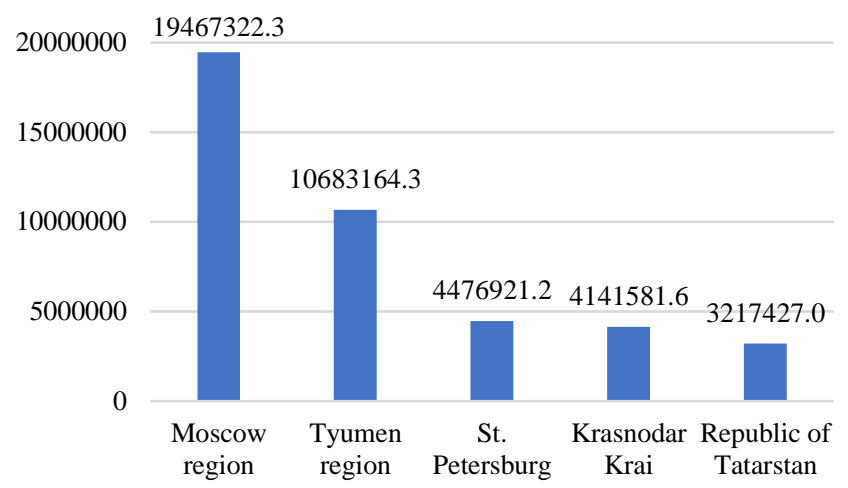

Fig. 3. The volume of shipped innovative products, work performed, services in the Moscow region in comparison with some regions of the Russian Federation, million rubles

The intensity of movement of the material flow in the Moscow region is accompanied by a high level of financial receipts in the innovation sphere. So, in 2019, internal expenditures on research and development in the Moscow region amounted to $45 \%$ of all expenditures in Russia and reached 520 billion rubles.

It is also possible to note the annual growth in the costs of innovative activities of organizations in this region. The value of this indicator grows annually by an average of $16.5 \%$ (Fig. 4).

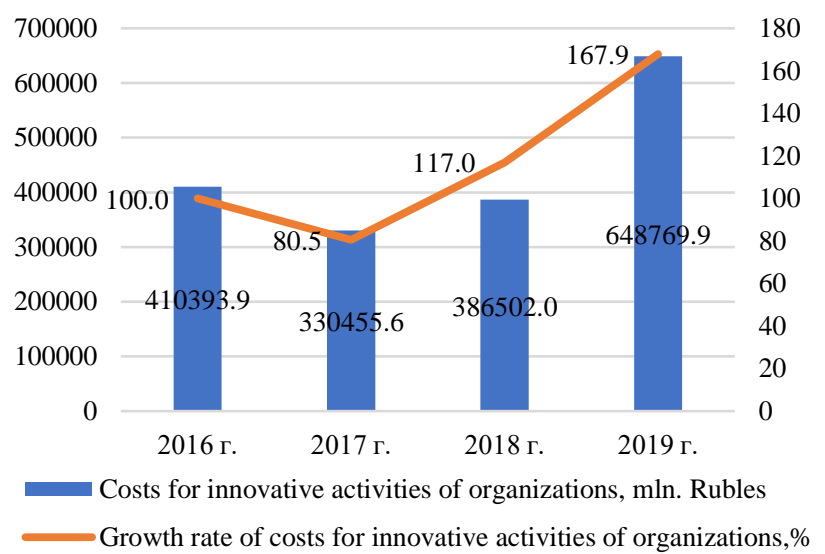

Fig. 4. Dynamics of costs for innovation activities of organizations in the Moscow region

In addition, the share of the Moscow region accounts for more than $1 / 3$ of all organizations' expenditures on innovative activities in the country.

Thus, the innovative development of the Moscow region is associated with the flow of significant flow processes, the management of which is the basis of the logistics approach. With the logistic approach, the movement of all flows, both main and accompanying, is carried out through logistic links [5]. 
In the general understanding, the logistics link is a separate, indivisible, within the framework of a certain logistic function, part of the system, which carries out its activities in strict accordance with the set goal.

The use of a logistic approach in the management of the innovative development of the region dictates the need to select logistics links in the regional innovation system. Logistic links of the regional innovation system can be grouped around the main ones, i.e. innovative, as well as related, i.e. material, financial, labor, etc., flows.

Within the framework of the main flow, innovative resources pass through three types of logistics links: generating, transforming and absorbing innovations [2].

At the level of the regional innovation system, generating logistics links include subjects of the scientific subsystem such as research institutes, universities, research centers, testing laboratories, etc. These logistics links are the basis for innovation. It is they who act as the main source of generation of innovative developments, and the scientific research carried out in them makes it possible to find new directions of development.

The transforming link in the logistics system of regional innovative development may include such elements as technology parks, business incubators and accelerators, technology transfer centers, etc. The main task of these logistics links is to provide favorable conditions for the subjects of innovation, which will contribute to the commercialization of innovative developments, i.e. transformation of novation into innovation.

The absorbing logistic link of the innovative regional system is, first of all, the subjects of entrepreneurial activity, both in the production sphere and in the sphere of circulation. They are the primary consumers of innovative developments. By absorbing the results of innovative activities of generating and transforming links, industrial enterprises ensure their mass production, and trade organizations carry out bringing innovations to the end consumer.

Almost all of the listed logistics links are present in the Moscow region. Leading research institutes, universities, testing laboratories engaged in research and development in various fields are concentrated here. These include the State University "Dubna" and the Joint Institute for Nuclear Research (developments in the field of nuclear physics), the Moscow Institute of Physics and Technology (scientific research in the field of nuclear physics, aircraft, medical devices and medicines), Central Research Institute for General Machine Building (scientific research in the field of creation and operation of aircraft), the Pushchino Scientific Center of the Russian Academy of Sciences (fundamental research in the field of physical and chemical biology and biotechnology) and many others.

The Moscow region occupies one of the leading positions in terms of the number of technoparks and business incubators located in it. Moreover, in this region there are 6 technoparks recognized as the most efficient in Russia in 2019. Among them, one is located in the Moscow region (Technopark "Istok") and 5 - in Moscow (Nanotechnological center "TechnoSpark", Technopolis "Moscow", Technopark "Kalibr", Technopark "Strogino", Technopark "Slava") [6]. In addition, there are 26 business incubators and 54 accelerators on the territory of Moscow and the Moscow Region that support the innovative business of the Moscow Region. In terms of the number of these logistic links, this region occupies a leading position among all regions of the Russian Federation. Thus, the transforming logistics links in the Moscow region are widely represented, which allows for providing innovative enterprises and organizations with effective support in the movement of the innovation flow.

Innovation flows are not only generated in the Moscow region, but are also actively absorbed by the subjects of the innovation process, as evidenced by Rosstat data on the use of advanced production technologies and intellectual property in Moscow and the Moscow Region. Thus, in 2019, 11\% of all advanced production technologies were used on the territory of the Moscow region, as well as 33\% of intellectual property objects in the country (Fig. 5).

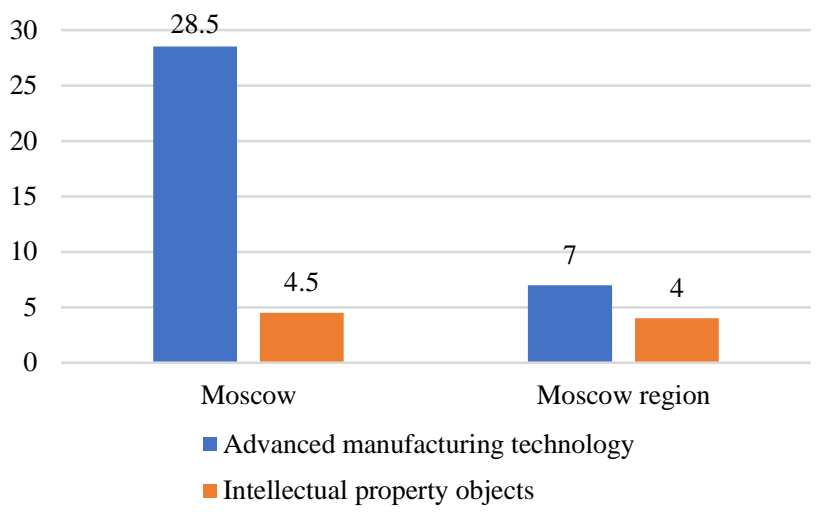

Fig. 5. The share of used advanced production technologies and intellectua property on the territory of the Moscow region of the total number of advanced production technologies and intellectual property used in the country, \%

At the same time, the largest number of intellectual property objects in the Moscow region is used for inventions and computer programs: $42 \%$ and $38 \%$ of the total set of used intellectual property objects in the territory of Moscow and the Moscow region, respectively.

Accompanying logistic flows also pass through certain logistic links of the regional innovation system, which can be represented by the following groups (Table I). As can be seen, the same logistic link can provide the movement of various accompanying flows. For example, the Foundation for Assistance to the Development of Small Forms of Enterprises in the Scientific and Technical Sphere is not only a source of movement of financial resources, but also provides consulting support to subjects of innovation, i.e. generates information flows. Logistic links, through which both the main and the accompanying flow pass, form a logistics system for the innovative development of the region. A special form of such a logistic system is innovative territorial clusters.

Innovative territorial clusters as a form of a macrological logistic system represent a stable interaction of independent subjects of innovation activity concentrated within one territory, whose efforts are aimed at maintaining the full cycle of movement of the main and accompanying flows of the innovation process in order to optimize the movement of innovative, material, financial and information resources between its logistic links [7] 
TABLE I. LOGISTIC LINKS OF THE ACCOMPANYING FLOWS OF THE REGIONAL INNOVATION SYSTEM

\begin{tabular}{|c|c|c|}
\hline $\begin{array}{c}\text { Type of an } \\
\text { accompanying } \\
\text { flow }\end{array}$ & $\begin{array}{l}\text { Group of } \\
\text { logistic links }\end{array}$ & $\begin{array}{c}\text { An example of a logistic link in the } \\
\text { Moscow region }\end{array}$ \\
\hline Material & $\begin{array}{l}\text { Manufacturing } \\
\text { enterprises } \\
\text { Wholesale and } \\
\text { retail trade } \\
\text { enterprises } \\
\text { Logistic } \\
\text { intermediaries }\end{array}$ & $\begin{array}{l}\text { JSC NPP “Istok" (Fryazino) } \\
\text { JSC "Metrovagonmash" (Mytishchi) } \\
\text { RSC "Energia" (Korolev) } \\
\text { JSC “Akrikh" (Moscow) } \\
\text { JSC "Valent Pharm" (Shchelkovo) }\end{array}$ \\
\hline Informational & $\begin{array}{l}\text { Federal services } \\
\text { Ministries and } \\
\text { departments } \\
\text { Consulting } \\
\text { agencies } \\
\text { Foundations }\end{array}$ & $\begin{array}{l}\text { Federal Service for Intellectual } \\
\text { Property Rospatent } \\
\text { Ministry of Investments, Industry and } \\
\text { Science of the Moscow Region } \\
\text { Ministry of Investments and } \\
\text { Innovations of the Moscow Region } \\
\text { Department of Science, Industrial } \\
\text { Policy and Entrepreneurship of the } \\
\text { City of Moscow } \\
\text { Department of Entrepreneurship and } \\
\text { Innovative Development of the City } \\
\text { of Moscow } \\
\text { State Budgetary Institution "Agency } \\
\text { of Innovations of Moscow" } \\
\text { ANO "Agency for Investment } \\
\text { Development of the Moscow Region" } \\
\text { Foundation for Assistance to Small } \\
\text { Innovative Enterprises in Science and } \\
\text { Technology }\end{array}$ \\
\hline Financial & $\begin{array}{l}\text { Private equity } \\
\text { and venture } \\
\text { capital funds } \\
\text { Banks }\end{array}$ & $\begin{array}{l}\text { Innovation Promotion Fund } \\
\text { Moscow Regional Fund for } \\
\text { Microfinance of Small and Medium } \\
\text { Business Entities } \\
\text { Industrial Development Fund of the } \\
\text { Moscow Region } \\
\text { JSC "Russian Venture Company" } \\
\text { Moscow Small Business Lending } \\
\text { Assistance Fund } \\
\text { Development Fund of the Center for } \\
\text { the Development of and } \\
\text { Commercialization on } \\
\text { Technologies (Skolkovo Foundation) } \\
\text { Russian corporation } \\
\text { nanotechnologies } \\
\text { Foundation for Assistance to Small } \\
\text { Innovative Enterprises in Science and } \\
\text { Technology } \\
\text { VEB Innovations }\end{array}$ \\
\hline
\end{tabular}

Five innovative territorial clusters are located on the territory of Moscow and the Moscow Region: "Zelenograd" (Moscow), New materials, laser and radiation technologies (Moscow), Biotechnological innovative territorial cluster (Pushchino, Chernogolovka), "Fiztech XXI" cluster (Dolgoprudny, Khimki) and the Cluster of Nuclear Physics and Nanotechnologies (Dubna).

Each of the presented clusters has its own focus and specificity of functioning, which determines the composition of its logistic links. For example, the Cluster of nuclear physics and nanotechnology, located in the city of Dubna, specializes in such areas as radiation technologies, nanostructured composite materials, nanobiotechnology. This cluster includes the following main logistic links (Table II).

The territorial innovation cluster of nuclear physics and nanotechnology includes logistic links that ensure the movement of all flows of the region's innovation system, which contributes to an increase in the efficiency of its functioning.
TABLE II. LOGISTIC LINKS OF THE TERRITORIAL INNOVATION CLUSTER OF NUCLEAR PHYSICS AND NANOTECHNOLOGY

\begin{tabular}{|c|c|c|}
\hline $\begin{array}{c}\text { Type of a } \\
\text { logistic flow }\end{array}$ & $\begin{array}{c}\text { Type of a } \\
\text { logistic link }\end{array}$ & Name of a logistic link \\
\hline \multirow{3}{*}{$\begin{array}{c}\text { Main } \\
\text { (Innovative) } \\
\text { Flow }\end{array}$} & Generating & $\begin{array}{l}\text { University "Dubna", Joint Institute for } \\
\text { Nuclear Research, Federal State Unitary } \\
\text { Enterprise "Research Institute of } \\
\text { Applied Acoustics", small and medium- } \\
\text { sized enterprises-members of the } \\
\text { cluster, performing R\&AD }\end{array}$ \\
\hline & Transforming & $\begin{array}{l}\text { MUP "Directorate for Development } \\
\text { Programs of the Science City "Dubna", } \\
\text { CJSC "IINC" Nanotechnological Center } \\
\text { "Dubna", LLC "Engineering Incubator" }\end{array}$ \\
\hline & Absorbing & $\begin{array}{l}\text { Industrial and commercial enterprises of } \\
\text { the Russian Federation, as well as } \\
\text { foreign countries (aircraft industry, } \\
\text { medicine, construction, gas supply, } \\
\text { etc.), state and municipal organizations, } \\
\text { individuals }\end{array}$ \\
\hline \multirow{3}{*}{ Accompanying } & Informational & $\begin{array}{l}\text { Administration of Dubna, Specialized } \\
\text { organization for cluster development - } \\
\text { Non-profit partnership "Dubna" }\end{array}$ \\
\hline & Financial & $\begin{array}{l}\text { Specialized organization for cluster } \\
\text { development }- \text { Non-profit partnership } \\
\text { "Dubna", Nanotechnology center } \\
\text { "Dubna", Skolkovo Foundation }\end{array}$ \\
\hline & Labor & $\begin{array}{l}\text { JINR Scientific Training Center (STC), } \\
\text { Personnel Training Center at Dubna } \\
\text { University, National Research Nuclear } \\
\text { University MIF }\end{array}$ \\
\hline
\end{tabular}

Thus, the territorial innovation cluster can be called a fairly effective macro-logistic system. It is the cluster that facilitates the unification of all participants in the innovation process into a single logistic chain on the way of movement of innovative and accompanying material, financial, informational and other flows from generating to absorbing logistic links [8]. In fact, the cluster provides logistical integration of all its elements, which is the basis for effective management of flow processes by achieving a synergistic effect from the functioning of this system. In this regard, it is the logistic approach that is the basis for the economic growth of territorial innovation clusters and, as a result, contributes to regional innovative development [9]. The use of the cluster approach increases the level of economic development of the region [10-14]

\section{CONCLUSION}

Logistics is the most important and indispensable component of the innovation processes taking place in the region. A logistic approach to managing regional innovative development optimizes the costs of reproducing innovations, which increases their competitiveness [10].

The logistic approach to managing the innovative development of the region includes such components as:

- organization of innovative processes based on the principle of consistency;

- rationalization of the main and auxiliary flow processes taking place in the regional innovation system;

- a compromise approach to decision-making, which ensures that the interests of all participants in innovation are taken into account;

- optimization of the costs of innovation through effective management of flow processes [3]. 
In this regard, in order to improve the efficiency of management of regional innovative development, it is necessary to build the innovative activity of the region, taking into account the main provisions of the logistic approach. First of all, it is necessary to accept the fact that flows, and not the system as a whole, become the object of control. Secondly, optimization of flow processes of the regional innovation system should be based on the principle of consistency. And, thirdly, this optimization should help mobilize the reserves for the growth of innovative activity in the region.

Thus, the level of innovative development of the region is largely due to the competent management of regional flow processes in the innovation sphere. This circumstance determines the need to use a logistic approach in the management of regional innovative development. The application of this approach allows for combining the efforts of all participants in the innovation process on the path of resource movement. Due to the receipt of a synergistic effect, the flow processes occurring in the regional innovation system are optimized, which ultimately accelerates the innovative development of the region in the context of the digital transformation of the country's economy.

\section{References}

[1] G. Abdrakhmanova, S. Artemov, P. Bakhtin et al., Russian Regional Innovative Scoreboard. Issue 6, Ed. L. Gokhberg, National Research University Higher School of Economics, Moscow: HSE, 2020, 266 p. (In Russ.).

[2] S.L. Parfyonova, "Logistics approach to innovation flows management", Science Governance and Scientometrics, 2014, vol. 9(1), pp. 148-159. (In Russ.).

[3] I.F. Elfimova, and R.S. Tokarev, "Management of innovative activity of enterprise on the basis of logistic approach", ECONOMINFO, 2018, vol. 15(4), pp. 22-27. (In Russ.).

[4] M.S. Oborin, and L.N. Starikova, "Specificity of organizing commercial logistics innovations", PNRPU Sociology and Economics Bulletin, 2018, vol. 3, pp. 303-315. (In Russ.).

[5] V.O. Pysmak, "Management of the innovative development of an enterprise based on the logistic approach", Business Inform, 2015, vol. 4(447), pp. 113-117.

[6] L.V. Danilov, E.A. Kashinova, E.I. Kravchenko, M.M. Bukharova, and M.A. Labudin, Fifth Annual Review "Russian Technology parks 2019", Moscow, Association for the Development of Clusters and Technology Parks of Russia, 2020, 110 p.

[7] I.V. Pustokhina, "Design of logistics clusters within the global logistics supply chain", Vestnik Universiteta, 2015, vol. 4, pp. 123-129. (In Russ.).

[8] T.V. Evtodieva, "Logistic clusters: essence and types" ["Logisticheskie klastery: sushchnost i vidy"], Economic Sciences, 2011, vol. 77. pp. 7881. (In Russ.).

[9] A.M. Magomedov, "Logistics cluster structure of regional economy", Modern problems of science and education, 2014, vol. 4, p. 364. (In Russ.).

[10] G.G. Levkin, and V.S. Bachmaga, "The use of a logistic approach in the activities of an enterprise when creating innovative products" ["Ispol'zovanie logisticheskogo podhoda v deyatel'nosti predpriyatiya pri sozdanii innovatsionnyh produktov"], Modern technologies of scientific research [Sovremennye kontseptsii nauchnykh issledovaniy] In Proceedings of IV ISPC, Nizhny Novgorod, 2015, pp. 150-154. (In Russ.).

[11] O.P. Ivanova, "Influence of regional industrial specialty to the emergence of intraregional clusters", Economy of Region, 2018 , vol. 14(4), pp. 1207-1220. (In Russ.).

[12] O.P. Ivanova, and Yu.V. Daneykin, "Investing in the infrastructure projects on the ASEDZ of monocities of RF", In European Proceedings of Social \& Behavioural Sciences, Published by the Future Academy, 2019, pp. 377-386.

[13] O.P. Ivanova, G.D. Antonov, V.A. Shabashev, L.L. Zobova, and A.Yu. Nesterov, "Formation of agro-industrial cluster on the priority social and economic development area of the mono-industry town", Foods and Raw Materials, 2017, vol. 5(1), pp. 192-204. DOI: 10.21179/2308-4057-2017-1-192-204

[14] O. Ivanova, G. Antonov, S. Bereznev, "The principles of municipal industrial clusters' establishment on the territory of advancing socialand-economic development of mono-town", In Proceedings of E3S Web of Conferences, 2017, 04001. DOI: https://doi.org/10.1051/e3sconf/20171504001 